J. Clin. Chem. Clin. Biochem.

Vol. 14,1976, pp. $521-526$

\title{
Oestrogen-Binding Components in Human Renal Cell Carcinoma
}

\author{
By H. Bojar, R. Dreyfürst, K. Balzer, W. Staib \\ Institut für Physiologische Chemie II, Universität Düsseldorf
}

and J. L. Wittliff

Department of Biochemistry, University of Rochester (N. Y.)

(Received May 7, 1976)

Summary: Specific binding-of $\left[{ }^{3} \mathrm{H}\right]$ oestradiol- $17 \beta$ by the cytosol fraction of human renal cell carcinoma was studied. The binding reaction displayed marked ligand specificity and high affinity of binding. Unlabelled oestradiol, oestriol and oestrone inhibited the binding of $\left[{ }^{3} \mathrm{H}\right]$ oestradiol- $17 \beta$ to the cytosol binding sites, whereas all other steroids tested turned out to be only weak or insignificant competitors for the oestrogen binding sites. Scatchard analyses suggested the existence of a single class of binding sites. The dissociation constant of the oestradiol-binder complex was found to be $2.51 \pm 0.75 \times 10^{-9} \mathrm{~mol} / \mathrm{l}$. The number of binding sites was limited $(17.5 \pm 3.8$ fmoles per $\mathrm{mg}$ of cytosol protein). Sucrose gradient centrifugation revealed these binding components to be macromolecules, either displaying a complex sedimentation pattern (peaks at $3.5 \mathrm{~S}, 4 \mathrm{~S}, 5.7 \mathrm{~S}$ and, in addition, high molecular weight aggregates) or sedimenting in the $4 \mathrm{~S}$ region alone. By agar gel electrophoresis it could be demonstrated that the oestradiol-binding components migrated into the receptor region of the gel. Binding of $\left[{ }^{3} \mathrm{H}\right]$ oestradiol- $17 \beta$ to these entities was markedly reduced, when the cytosol was heated $\left(60 \mathrm{~min}\right.$ at $\left.45^{\circ} \mathrm{C}\right)$ prior to the reaction with the labelled hormone. Since the specific binding components exhibit properties of oestradiol receptors in target tissues, a direct effect of oestradiol on human renal cell carcinoma is suggested.

\section{Östrogen-bindende Komponenten in hypernephroiden Karzinomen des Menschen}

Zusammenfassung: Die spezifische Bindung von $\left[{ }^{3} \mathrm{H}\right]$ Östradiol-17 $\beta$ durch die Cytosolfraktion hypernephroider Nierenkarżinome des Menschen wurde untersucht. Die Bindungsreaktion zeigte eine ausgeprägte Spezifität und hohe Affinität. Unmarkiertes Östradiol, Östriol und Östron hemmten die Bindung von $\left[{ }^{3} \mathrm{H}\right]$ Östradiol-17 $\beta$, während alle übrigen getesteten Steroide sich nur als schwache bzw. nicht signifikante Kompetitoren erwiesen. Scatchard-Analysen deuten auf nur eine Klasse von Bindungsstellen hin. Die Dissoziationskonstante des Östradiol-Binderkomplexes betrug $2,51 \pm 0,75 \mathrm{nmol} / 1$. Dịe Z̈ahl der Bindungsstellen wạr limitiert (17,5 $\pm 3,8 \mathrm{fmol} / \mathrm{mg}$ Cytosolprotein). Saccharosegradientenzentrifugation zeigte, daß diese Bindungskomponenten Makromoleküle waren. Das Sedimentationsprofil war entweder komplex (Maxima bei 3,5S, 4S, 5,7S und zusätzlich hochmolekulare Aggregate) oder zeigte nur ein Maximum in der 4S=Region. Durch Agarelektrophorese konnte demonstriert werden, daß die östradiolbindenden Komponenten in die Rezeptorregion des Gels wạnderten. Die Bindung des tritiierten Hormons an diese Moleküle nahm erheblich ab, wenn das Cytosol vor der Reaktion mit dem radioaktiv markierten Östradiol erhitzt wurde (60 min bei $45^{\circ} \mathrm{C}$ ). Da die spezifischen Bindungskomponenten Ëigenschaften von Östradiolrezeptoren in Zielorganen haben, wird eine direkte Wirkung von Östradiọl auf hypernephroide Karzinome des Menschen erwartet.

\section{Introduction}

Between 70 and 80 per cent of all malignant kidney tumours are renal cell carcinomas. (1). Even if at the time of nephrectomy no distant metastases çan be detected, about 50 per cent of the patients die within 5 years after removal of the primary tumour (1). Radiotherapy of advanced renal cancer as well as treatment with cytotoxic drugs have been disappointing $(2,3)$. In this situation Bloom (4), Samuels (5), Paine (6) and Brühl (1) have drawn attention to the possibility of achieving significant tumour regression in a limited number of patients with renal carcinoma by administering steroid hormones. The concept of an endocrine dependence of renal cancer in 
man was derived from an oestrogen-induced renal adenocarcinoma of the male golden hamster $(7,8)$. The histological appearance of this tumour was found to be similar to that of human carcinoma (9). Anti-oestrogens, testosterone and progestagens markedly inhibited the production and growth of these tumours $(8,10,11)$. Furthermore, clear evidence has been accumulated on the presence of oestrogen receptors in hamster tumours (12, 13). However, caution is necessary when extrapolating from observations in laboratory animals to clinical practice (4). Moreover, only a limited number of patients respond to hormonal therapy. Consequently, it is desirable to select those patients who are most likely to respond. Therefore, information on steroid hormone receptors in human renal carcinoma may be useful in supporting the hormonal background of these tumours, and in the design of a well-controlled therapy for advanced renal cancer in man. This paper describes the detection of specific oestrogen binding components in renal cell carcinoma of man.

\section{Materials and Methods}

\section{Chemicals and Reagents}

$\left[2,4,6,7-{ }^{3} \mathrm{H}\right]$ oestradiol $-17 \beta(110 \mathrm{Ci} / \mathrm{mmol})$ and Omnifluor were obtained from New England Nuclear. All unlabelled hormones were purchased from Calbiochem. Serva served as a source of Norit A, while Dextran T 500 was obtained from Pharmacia. Agar purum and bovine serum albumin were obtained from Behring, Marburg. All other chemicals were commercial preparations of analytical grade.

\section{Patients}

In 1974 and 1975 six male patients, aged 58 to 79 , with a massive unilateral kidney tumour and no detectable metastases were nephrectomized at the Urologische Klinik der Universität Düsseldorf. All patients had neither been subjected to preoperative irradiation nor treatment with cytotoxic drugs.

\section{Collection and Handling of Tumour Specimens}

Immediately after removal of the primary tumour, specimens were taken, debribed of necrotic and hemorrhagic areas, and instantly immersed in liquid nitrogen. Routinely, paraffin sections, 8 to $10 \mu \mathrm{m}$ thick, were made from samples of the tissue obtained. They were stained with hematoxilin and eosin and then examined microscopically to ensure that the specimens analysed for oestrogen-binding components were renal carcinomas.

\section{Preparation of Tumour Cytosols}

Solid specimens $(3-7 \mathrm{~g})$, which had been stored in liquid nitrogen prior to use, were placed in ice-cold Tris buffer $A(10 \mathrm{mmol} / 1$ Tris- $\mathrm{HCl}, 1.5 \mathrm{mmol} / 1 \mathrm{Na}{ }_{2}$ EDTA, $\mathrm{pH}$ 7.4) or Tris buffer B ( $10 \mathrm{mmol} / 1 \mathrm{Tris}-\mathrm{HCl}, 1 \mathrm{mmol} / 1 \mathrm{Na}_{2}$ EDTA, $0.25 \mathrm{~mol} / 1$ sucrose, $\mathrm{pH}$ 8.0) and allowed to stand at $3^{\circ} \mathrm{C}$ until thawed. The samples were then minced roughly and stirred gently in the same medium $(1: 10, w / v)$ for $10 \mathrm{~min}$ to remove contaminating blood. Subsequently, the washed tissue was homogenized in a Dual homogenizer with cold Tris buffer A or B $(1: 3, w / v)$. Finally, the homogenate was centrifuged at $105000 \mathrm{~g}\left(3^{\circ} \mathrm{C}\right)$ for $30 \mathrm{~min}$ and the supernatant (cytosol) carefully removed with a Pasteur pipette.

\section{Dextran-Coated Charcoal Assay}

This method was based on Korenman's procedure (14). Cytosols ( $0.2 \mathrm{ml}$ portions), prepared in Tris buffer $\mathrm{B}$, were reacted with $0.2-4.0 \mathrm{nmol} / \mathrm{l}\left[{ }^{3} \mathrm{H}\right.$ ]oestradiol-1.7. $\beta$ for $14 . \mathrm{hr}$ at $0-3^{\circ} \mathrm{C}$, either alone or in the presence of unlabelled competitive hormones at $1 \mu \mathrm{mol} / \mathrm{l}$. Details of individual experimental designs are given in the legends to figures and tables. Subsequent to the incubation the samples were comibined with $0.5 \mathrm{ml}$ of $5 \mathrm{~g} / \mathrm{l}$ Norit $\mathrm{A}, 50 \mathrm{mg} / \mathrm{l}$ Dextran T 500, $10 \mathrm{mmol} / 1$ Tris- $\mathrm{HCl}, 1 \mathrm{mmol} / 1 \mathrm{Na}_{2}$ EDTA, 0.25 $\mathrm{mol} / \mathrm{l}$ sucrose at $\mathrm{pH} 8.0$. The mixture was incubated at $0-3^{\circ} \mathrm{C}$ for $5 \mathrm{~min}$ and then centrifuged for $2 \mathrm{~min}$ at $12000 \mathrm{rev} . / \mathrm{min}$ in an Eppendorf centrifuge, model 3200 . Portions $(0.2 \mathrm{ml})$ of the supernatant fluid were pipetted into scintillation vials together with $10 \mathrm{ml}$ of Bray's scintillation fluor (15) for counting of radioactivity.

\section{Sucrose Gradient Centrifugation}

The assay procedure closely paralleled the one originally described by Toft \& Gorski (16). Briefly, aliquots $(200 \mu \mathrm{l})$ of cytosol, prepared in Tris buffer $A$, were reacted with $\left[{ }^{3} \mathrm{H}\right]$ oestradiol-17 $\beta$ for

$2 \mathrm{hr}$ at $0-3^{\circ} \mathrm{C}$ either alone or in the presence of unlabelled hormones at $1 \mu \mathrm{mol} / \mathrm{l}$. Portions $(500 \mu \mathrm{l})$ of $5 \mathrm{~g} / \mathrm{l}$ Norit $\mathrm{A}$, $50 \mathrm{mg} / 1 \mathrm{Dextran}$ T $500,10 \mathrm{mmol} / 1$ Tris- $\mathrm{HCl}, 1.5 \mathrm{mmol} / \mathrm{l} \mathrm{Na} 2$ EDTA at pH 7.4 were centrifuged for $2 \mathrm{~min}$ at $12000 \mathrm{rev} / \mathrm{min}$ in an Eppendorf centrifuge. The supernatants were discarded. The labelled cytosols were then mixed with the charcoal pellets and processed as described under dextran-coated charcoal assay. The supernatant fluids were assayed for receptor activity by layering over linear 50-200 g/l sucrose gradients in Tris buffer A. These gradients were centrifuged in a Beckman L2-65 B preparative ultracentrifuge for $16 \mathrm{~h}$ at $56000 \mathrm{rev} . / \mathrm{min}\left(0^{\circ} \mathrm{C}\right)$ using a Spinco SW 56 titanium rotor. After centrifugation, the bottom of the tubes were pierced and a 6-drop fraction collected into scintillation vials containing $2 \mathrm{ml}$ ethanol (99\%). Ten $\mathrm{ml}$ of toluene scintillation cock tail ( $4 \mathrm{~g}$ of Omnifluor/1 toluene) were added to each fraction and the radioactivity measured.

Protein Determination

Protein was estimated by Lowry's method (17) using bovine serum albumin as a standard.

\section{Agar Gel Electrophoresis}

Electrophoresis closely paralleled that originally described by Wagner (18). Briefly, tumour specimens $(1-2 \mathrm{~g})$ which had been stored in liquid nitrogen, werc pulverized in three volumes of Tris buffer $\mathrm{C}(10 \mathrm{mmol} / 1 \mathrm{Tris}-\mathrm{HCl}, 1 \mathrm{mmol} / 1$ $\mathrm{NaN}_{3}$, pH 7.5) in a mortar chilled with liquid nitrogen. The powder was allowed to thaw at $4^{\circ} \mathrm{C}$. Subsequently, the thawed homogenate was centrifuged at $105000 \mathrm{~g}\left(3^{\circ} \mathrm{C}\right)$ for $30 \mathrm{~min}$ in order to prepare the cytosol. Cytosols ( $0.2 \mathrm{ml}$ portions) were incubated for $2 \mathrm{hr}$ at $0-3^{\circ} \mathrm{C}$ with $10 \mathrm{nmol} / 1{ }^{3} \mathrm{H}$ )oestradiol-17 $\beta$. Non-specific binding of the hormone was determined in parallel incubations with cytosols, which had been heated for $1 \mathrm{hr}$ at $45^{\circ} \mathrm{C}$. Following the incubation, $50 \mu \mathrm{l}$ portions of the cytosols were pipetted into each of the 10 sample-wells punched at the center line of the agar slab. During electrophoresis (130 $\mathrm{mA} ; 70 \mathrm{~min})$, the temperature in the receptor region of the gel was continuously monitored by an epoxycoated extra small ther mistor (Yellow Spring Instrument Co, part \# 44202) and maintained at $3-4^{\circ} \mathrm{C}$ by cooling of the tefloncoated brass block. After the run, the individual analyses were separated by lengthwise slicing the gel slab. The strips were cut into $5 \mathrm{~mm}$ sections with a razor-blade. The samples were placed into wire-gauze baskets, coated with a thin layer of black paper. The strips were then dried at $60^{\circ} \mathrm{C}$ for $12 \mathrm{~h}$. Using sample holders attached to screw caps (BF-Vertricbs GmbH, Karlsruhe), the baskets were placed into glass scintillation counting vials, containing $0.5 \mathrm{ml}$ distilled water. With the aid of a simple device up to 40 vials were evacuated and filled with oxygen (19). The screw caps were then sealed gas tight and automatic in-vial combustion started, using the Micro-Mat BF 5010 (BFVertriebs $\mathrm{GmbH}$, Karlsruhe). This procedure is a modification of the technique originally described by Gupta (20). When 
combustion of the samples was complete, the vials were allowed to stand at $-10^{\circ} \mathrm{C}$ for about $5 \mathrm{~min}$ in order to completely condense the tritium water-vapor. Subscquently, the special sample holders were removed, $10 \mathrm{ml}$ of Bray's scintillation fluor (15) added to each vial, and the samples were ready for liquid scintillation counting.

\section{Results}

For determination of the nature of the molecular species binding oestrogen, cytosols prepared from human renal cell carcinoma were reacted in vitro with $\left[{ }^{3} \mathrm{H}\right]$ oestradiol$17 \beta$ and then analyzed by the dextran-coated charcoal procedure, sucrose density gradient centrifugation, and agar gel electrophoresis.

\section{Use of the Dextran-Coated Charcoal Assay}

The charcoal adsorption assay was used to estimate the affinity of the binding components for $17 \beta$-oestradiol, and to ascertain the relative affinities of other steroid hormones for the oestradiol-binding entities.

\section{Titration of the cytosol}

The affinity of oestradiol binding to cytoplasmic components of renal cell carcinoma was determined by incubating the cytosol with increasing concentrations of $\left[{ }^{3} \mathrm{H}\right]$ oestradiol-17 $\beta$. At each concentration the specific binding was determined by subtracting the amount of tritiated hormone complexed non-specifically in an identical reaction, containing the same concentration of $\left[{ }^{3} \mathrm{H}\right]$ oestradiol- $17 \beta$ but in addition unlabelled oestradiol at $1 \mu \mathrm{mol} / \mathrm{l}$. Saturation type binding curves were obtained (not shown). To estimate the dissociation constant of the oestradiol-binder complex and the maximal number of binding sites, the results were analyzed by the Scatchard method (21). As can be seen in Figure 1, a plot of the concentration of oestradiol bound versus the ratio of bound over free oestradiol closely approximates to a straight line. From the slopes of Scatchard plots over the indicated range of hormone concentrations the dissociation constants for the reaction: oestradiol + binder $F=$ oestradiol-binder complex was calculated and found to be $2.51 \pm 0.75 \times 10^{-9}$ mol $/ 1$ (mean \pm SEM of four individual experiments). Assuming that the binding entities are univalent and that only a single class of specific binding components exists under the conditions of the assay, the maximal concentration of the binding entities was determined to be $17.5 \pm 3.8$ fmoles per $\mathrm{mg}$ of cytosol protein (mean \pm SEM of four individual experiments), ranging from 10 to $2 \overline{7}$ fmoles per $\mathrm{mg}$ of protein.

\section{Ligand specificity}

The relative affinities of various steroids for the $17 \beta$-oestradiol binding components, as measured by

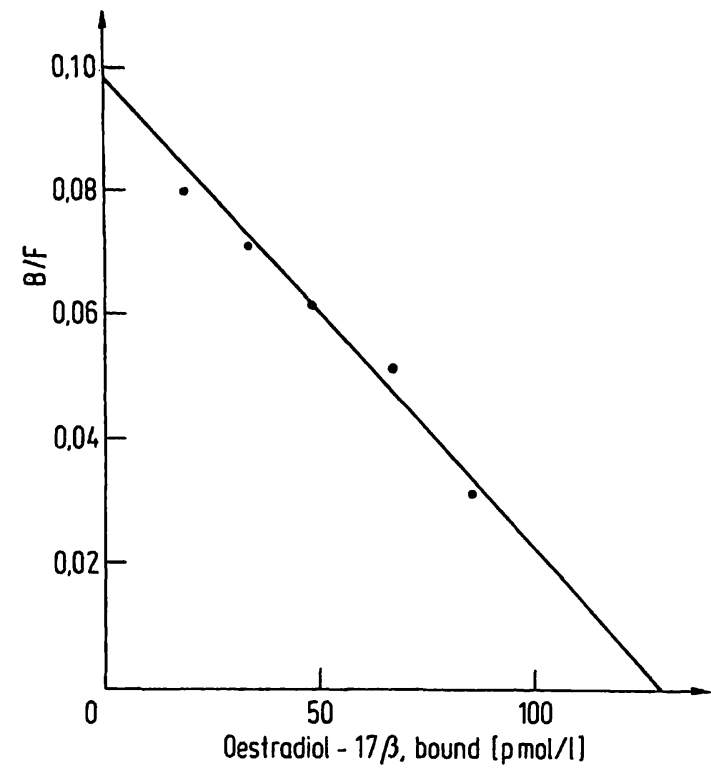

Fig. 1. Scatchard analysis of the titration data for the oestrogenbinding components in the cytosol of human renal cell carcinoma. $105000 \mathrm{~g}$ supernatants $(0.2 \mathrm{ml}$ portions), prepared in Tris buffer $B$, were reacted with increasing concentrations of $\left.\right|^{3} \mathrm{H}$ joestradiol-17 $\beta(0.2-3.7 \mathrm{nmol} / \mathrm{l})$ at $0-3^{\circ} \mathrm{C}$ for $14 \mathrm{~h}$ either alone or in the presence of unlabelled $17 \beta$-oestradiol at $1 \mu \mathrm{mol} / \mathrm{l}$. Binding was measured by the dextran-coated charcoal assay. $\mathrm{K}_{\mathrm{D}}=1.3 \times 10^{-9} \mathrm{~mol} / \mathrm{l}$.

competition studies, are summarized in Table 1 . The ligand specificity for binding to these entities indicated a requirement for oestrogens. These results are similar to those reported for normal human kidney (22). Progesterone turned out to be a moderate competitor for oestrogen binding sites. Weak inhibition of oestradiol binding was observed in the presence of cortexolone, while aldosterone, corticosterone, cortisol and dihydrotestosterone seem to compete only insignificantly with oestradiol for binding to these sites.

Tab. 1. Ligand specificity of $\left[{ }^{3} \mathrm{H}\right]$ oestradiol- $17 \beta$ binding by cytosol from human renal cell carcinoma. Cytosols $(0.2 \mathrm{ml}$ portions), prepared in Tris buffer $\mathrm{B}$, were incubated with $4 \mathrm{nmol} / 1\left[{ }^{3} \mathrm{H}\right]$ oestradiol $-17 \beta$ for $14 \mathrm{~h}$ at $0-3^{\circ} \mathrm{C}$, either alone or in the presence of a competitive substance at $1 \mu \mathrm{mol} / \mathrm{l}$. Each reaction was terminated by the addition of $0.5 \mathrm{ml}$ of the dextran-coated charcoal reagent. Inhibition of specific $\left[{ }^{3} \mathrm{H}\right]$ oestradiol-17 $\beta$-binding is expressed as percentage of control value.

\begin{tabular}{lc}
\hline Competitive Substance & $\begin{array}{l}\text { Inhibition of Specific } \\
{\left[{ }^{3} \mathrm{H}\right] \text { Oestradiol-17 } \beta} \\
\text { Binding [\%] }\end{array}$ \\
\hline None & 0 \\
Oestradiol & 100 \\
Oestriol & 75 \\
Oestrone & 78 \\
Progesterone & 26 \\
Dihydrotestosterone & 3 \\
Cortisol & 5 \\
Corticosterone & 9 \\
Cortexolone & 18 \\
Aldosterone & 11 \\
\hline
\end{tabular}




\section{Sucrose Gradient Centrifugation}

Isotopic profiles of the cytoplasmic oestradiol binding components separated on low ionic strength sucrose density gradients (50-200 g/1), are shown in Figure 2. Specific binding is indicated by the difference in the areas under the peaks, obtained in the absence (closed circles) or presence (open circles) of an excess of unlabelled $17 \beta$-oestradiol. Analysing the cytosols from different renal cell carcinomas, two distinct types of isotopic profiles were obtained. In both plots (Fig. 2, profile A and profile B) specific binding of $17 \beta$-oestradiol to macromolecular species, sedimenting in the 4.2-4.4S region of the gradient, can be seen. In profile $\mathrm{A}$ (Fig. 2), however, additional specific binding components at about $3.5 \mathrm{~S}$ and $5.7 \mathrm{~S}$ are discernible. Moreover, a significant fraction of the radioactivity was recovered at the bottom of the tube, thus, exhibiting a high sedimentation coefficient. It therefore appears that at low ionic strength

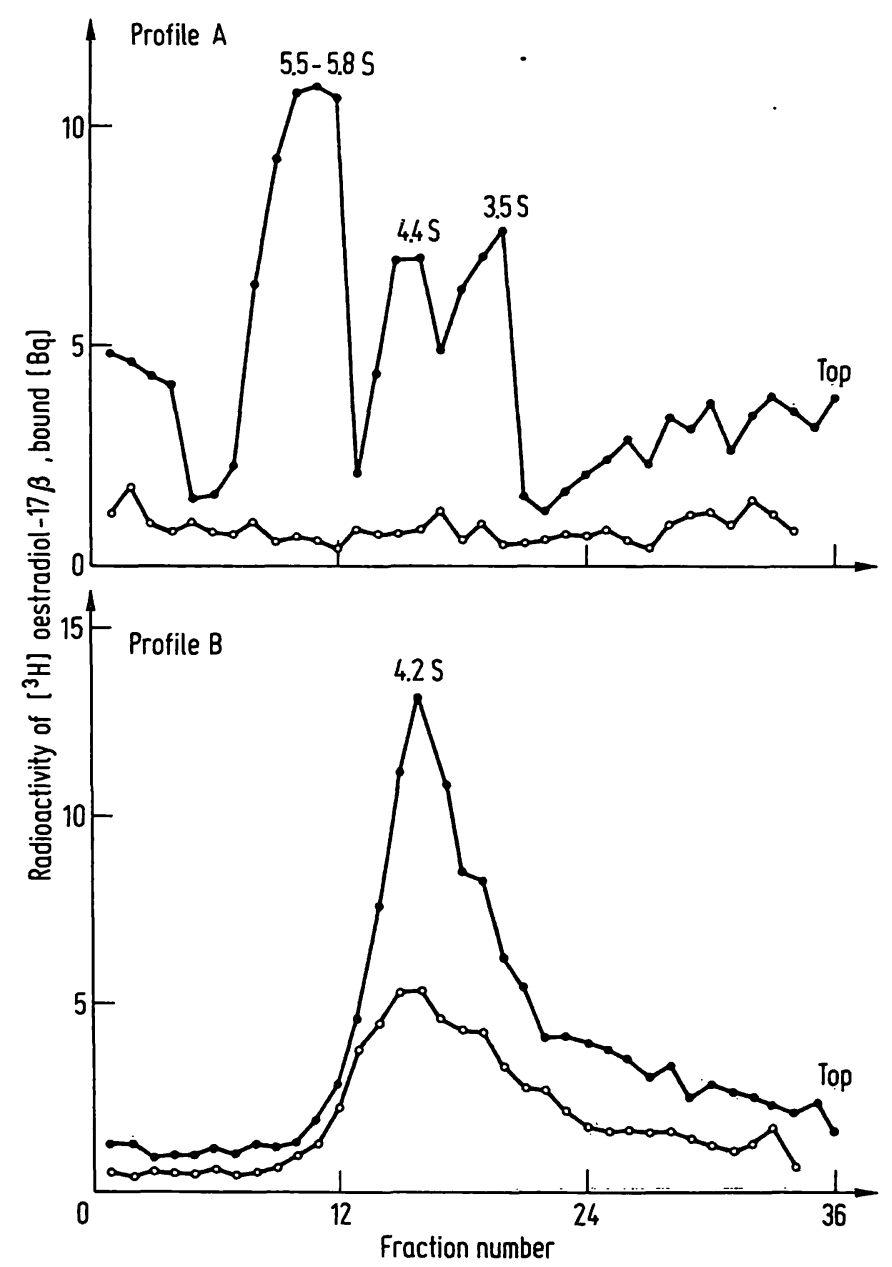

Fig. 2. Representative isotopic profiles of oestrogen-binding macromolecules, separated by sucrose gradient centrifugation of cytosols, obtained from human renal cell carcinoma. Aliquots $(0.2 \mathrm{ml})$ of cytosol, prepared in Tris buffer A, were incubated with $3 \mathrm{nmol} / 1\left[^{3} \mathrm{H}\right]$ oestradiol-17 $\beta$ for $2 \mathrm{~h}$ at $0-3^{\circ} \mathrm{C}$ either alone (closed circles) or in the presence of unlabelled oestradiol at $1 \mu \mathrm{mol} / \mathrm{l}$ (open circles). The cytosols were subjected to dextran-coated charcoal treatment and then assayed for binding activity by layering over linear 50-200 g/l sucrose gradients in Tris buffer A. The gradients were centrifuged for $16 \mathrm{~h}$ at $56000 \mathrm{rev} . / \mathrm{min}$ $\left(0^{\circ} \mathrm{C}\right)$ using a Spinco SW 56 titanium rotor.
$17 \beta$-oestradiol forms a complex with cytosol macromolecules which tends to aggregate. All peaks represent saturable steroid binding sites, for binding is inhibited by an excess of unilabelled oestradiol.

\section{Agar Gel Electrophoresis}

For further characterisation of the oestrogen binding components in human renal cell carcinoma, the cytosol was submitted to agar gel electrophoresis at low temperature (Fig. 3). The assay discriminates between receptor proteins

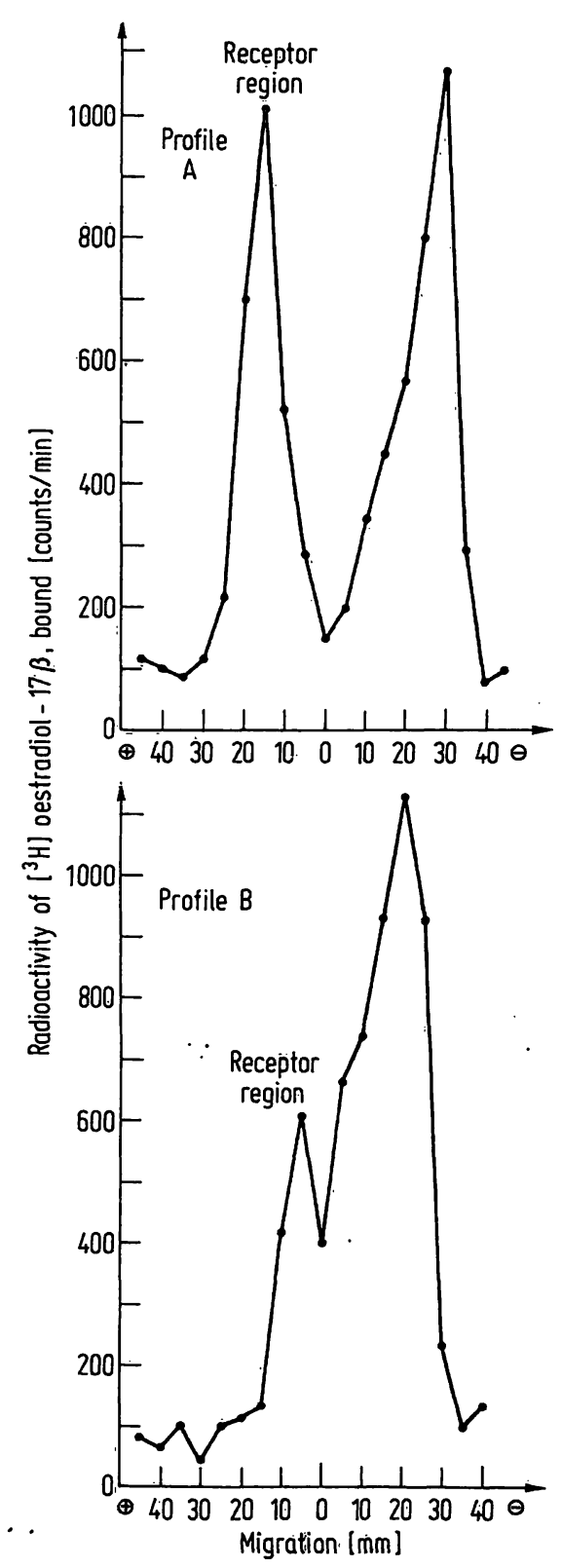

Fig. 3. Electrophoretic separation of cytoplasmic oestrogenbinding components from human renal cell carcinoma. Cytosols were reacted with $\left.10 \mathrm{nmol} /\left.1\right|^{3} \mathrm{H}\right]$ oestradiol-17 $\beta$ for $2 \mathrm{~h}$ at $0-3^{\circ} \mathrm{C}$ (Profile $\mathrm{A}$ ). The heat lability of the binding components was determined in parallel incubations with cytosol, which had been heated for $1 \mathrm{~h}$ at $45^{\circ} \mathrm{C}$ (Profile B). Aliquots (50 $\mu$ l) of the cytosols were then - separated by agar gel electrophoresis $(10 \mathrm{~g} / 1$ agar gel, $130 \mathrm{~mA}, 70 \mathrm{~min}, 3-4^{\circ} \mathrm{C}$ gel temperature). $5 \mathrm{~mm}$ sections were countedi after in vial combustion. 
and sex-hormone-binding globulin which may be present in human tissue extracts due to serum contamination (18). Receptor proteins migrate towards the anode, whereas sex-hormone-binding globulin and free oestradiol move towards the cathode. Moreover, high affinity binding to receptor sites can be distinguished from low affinity binding to serum contaminants, the oestradiol complexes of which do not withstand agar gel electrophoresis. As can be seen in profile A (Fig. 3), high affinity binding of $\left[{ }^{3} \mathrm{H}\right]$ oestradiol- $17 \beta$ could be clearly demon-

- strated in the receptor region of the gel. In profile $B$

(Fig. 3), the heat lability of these binding components is shown. In this experiment, the cytosol was heated for $60 \mathrm{~min}$ at $45^{\circ} \mathrm{C}$ prior to the reaction with the tritiated hormone. It can be clearly seen that the majority of the binding entities in the receptor region displayed a heat lability, which closely resembles that of oestrogen receptors in target tissues (23).

\section{Discussion}

The results presented here demonstrate the existence of oestradiol binding components in the cytoplasmic fraction of human renal cell carcinoma. The ligand specificity for binding to these components compares well with that of normal rat (24) and human kidney (22). The fact that a large excess of unlabelled aldosterone did only weakly compete with tritiated $17 \beta$-oestradiol for binding to these entities, suggests that the oestradiol-binding sites are independent of mineralocorticoid receptors. The inability of dihydrotestosterone to compete with oestradiol for binding to these components clearly excludes a "crossaffinity" of $17 \beta$-oestradiol for an androgen receptor, which may be present in renal cell carcinomas of male patients. Interestingly, progesterone, which is known to cause a significant tumour regression in a limited number of patients with renal cell carcinoma $(4,5,6)$ turned out to be a moderate competitor of $\left[{ }^{3} \mathrm{H}\right]$ oestradiol- $17 \beta$ binding to these components. By agar gel electrophoresis it could be demonstrated, that the oestradiol-binding entities exhibited an electrophoretic mobility, which was different from that of sex-hormone-binding globulin and which closely resembles that of oestrogen receptors in target tissue $(18,23)$. The heat lability of the binding components provides further presumptive evidence for these binding sites being oestrogen receptors (23). The binding reaction displayed saturation kinetics and high affinity binding of the hormone to cytosol macromolecules. The dissociation constant of the binder-ligand complex from the cytoplasmic fraction of human renal cell carcinoma $\left(2.51 \pm 0.75 \times 10^{-9} \mathrm{~mol} / \mathrm{l}\right)$ is strikingly similar to that of normal human kidney $\left(2.2 \pm 0.1 \times 10^{-9} \mathrm{~mol} / \mathrm{l}\right)$, R $3230 \mathrm{AC}$ rodent mammary adenocarcinoma $\left(1.2 \times 10^{-9}\right.$ $\mathrm{mol} / \mathrm{l})$, and human breast carcinoma $\left(0.9 \times 10^{-9} \mathrm{~mol} / \mathrm{l}\right)$ $(22,25,26)$. The binding capacity of the cytosol of human renal cell carcinoma was found to be $17.5 \pm 3.8$ fmoles per mg of cytosol protein. In comparison to this value, the oestradiol receptors in normal human kidney cytosol (22) appear to be of higher capacity $(34.0 \pm 9.7$ fmoles/mg protein). Similar to human breast carcinoma (26), the oestrogen binding capacity of cytosol prepared from different tumour specimens varied considerably (10-27 fmoles/mg protein). It seems reasonable to assume, that the variability of the number of binding sites reflects interindividual differences in the receptor content. Moreover, it is most likely, that the oestrogenbinding components are not evenly distributed among the tumour tissue. These intraindividual variations in receptor content may be due to the obvious heterogeneity of the tumour cell population. The sedimentation patterns of the oestradiol-binding entities on sucrose density gradients display interindividual and/or intraindividual variations. However, in both profiles (Fig. 2, profile A and B) sedimentation of the binderligand complex at about $4 \mathrm{~S}$ can be seen. This sedimentation behaviour is very similar to that of inactivated receptor complexes in various target organs. It remains to be elucidated whether the peak at $3.5 \mathrm{~S}$ (Fig. 2, profile A) indicates specific binding to biosynthetic precursors of the oestradiol receptors ( $P$. W. Jungbluth, pers. communication). Although, further studies are required, to shed light on the nature of the $5.5-5.8 \mathrm{~S}$ peak (Fig. 2, profile A), it is tempting to suppose that this peak represents binding of the hormone to the active receptor dimer, sedimenting in the $5 \mathrm{~S}$ region (P. W. Jungbluth, pers. communication, (27)). The finding of oestradiol-binding components, which display characteristics of oestrogen receptors in target organs, raises a number of intriguing questions. Is the presence of such a binding component in human renal cell carcinoma merely incidental? If this is not so, what is the function and significance of such receptor sites in tumour cell metabolism? Do all renal cell carcinomas contain oestradiol receptors? Is the occurrence of receptor molecules restricted to a subpopulation of tumour cells? Experiments to determine the exact cellular source in human renal cell carcinoma for the oestrogenbinding components are in progress.

\section{Acknowledgements}

This investigation was supported by the Minister für Wissenschaft und Forschung des Landẹ Nordrhein-Westfalen.

\section{References}

1. Brühl, P., Scheef, W., Albert, H. \& Bücheler, E. (1974), Deutsches Ärzteblatt 71, 2919-2927.

2. Woodruff, M. W., Wagle, D., Gailini, S. D. \& Jones, R. (1967), J. Urol. 97, 611-618.
3. Talley, R. W., Moorhead, E. L., Tucker, W. G., San Diego, E. L. \& Brennan, M. J. (1969), J. Amer. Med. Ass. 207, 322-328.

4. Bloom, H. J. G. (1971), Brit. J. Cancer 25, 250-265. 
5. Samuels, M. L., Sullivan, P. \& Howe, C. D. (1968), Cancer, N. Y. $22,525-532$.

6. Paine, C. H., Wright, F. W. \& Ellịs, F. (1970), Brit. J. Cancer 24, 277-282.

8. Kirkham, H. (1959), Nat. Cancer Inst. Monogr. 1, 1-59.

9. Horning, E. S. \& Whittick, J. W. (1954), Brit. J. Cancer 8, $451-457$.

10. Bloom, H. J. G., Roe, F. J. C. \& Mitchley, B. C. V. (1967), Cancer N. Y. 20, 2118-2124.

11. Horning, E. (1956), Z. Krebsforsch. 61, 1-21.

12. Steggles, A. W. \& King, R. J. B. (1968), Europ. J. Cancer 4, 395-400.

13. Steggles, A. W. \& King, R. J. B. (1972), Europ. J. Cancer. 8 , $323-334$

14. Korenman, S. G. (1968), J. Clin. Endocrinol. Metab. 28, 127-130.

15. Bray, G. A. (1961), Anal. Biochem. 1, 279-285.

16. Toft, D. \& Gorski, J. (1966), Proc. Nat. Acad. Sci. U.S. 55, 1574-1581.

17. Lowry, O. H., Rosebrough, A. L., Farr, A. L. \& Randall, R. J. (1951), J. Biol. Chem. 193, 265-275.
18. Wagner, R. K. (1972), Hoppe Seyler's. Z. Physiol. Chem. $353,1235-1245$.

19. Wegner, L. A. \& Winkelmann, H. (1970), Atompraxis 16, 19-26.

20. Gupta, G. N. (1966), Analyt. Chem. 38, 1356-1359.

21. Scatchard, G. (1949), Ann. N. Y. Acad. Sci. 51, 660-672.

22. Bojar, H., Balzer, K., Dreyfürst, R., Staib, W. \& Wittliff, J. L. (1976), this J. 14, 515-520.

23. Wagner, R. K. (1970), Symp. Dtsch. Ges. Endokrin. 16, 407-409.

24. De Vries, J. R., Ludens, J. H. \& Fanestiel, D. D. (1972), Kidney International 2, 95-100.

25. Wittliff, J. L., Gardner, D. G., Battema, W. L. \& Gilbert, P. J. (1972), Biochem. Biophys. Res. Commun. 48, 119-125.

26. Wittliff, J. L., Hilf, R., Brooks, W. F., Savlov, E. D., Hall, T. C. \& Orlando, R. A. (1971), Cancer Research 32, 1983 $-1992$.

27. Shymala, G. \& Gorski, J. (1969), J. Biol. Chem. 244, 1097-1103.

Dr. H. Bojar

Institut für Physiologische Chemie II

Universität Düsseldorf

Mooerenstraße 5

D-4000 Düsseldorf 1 